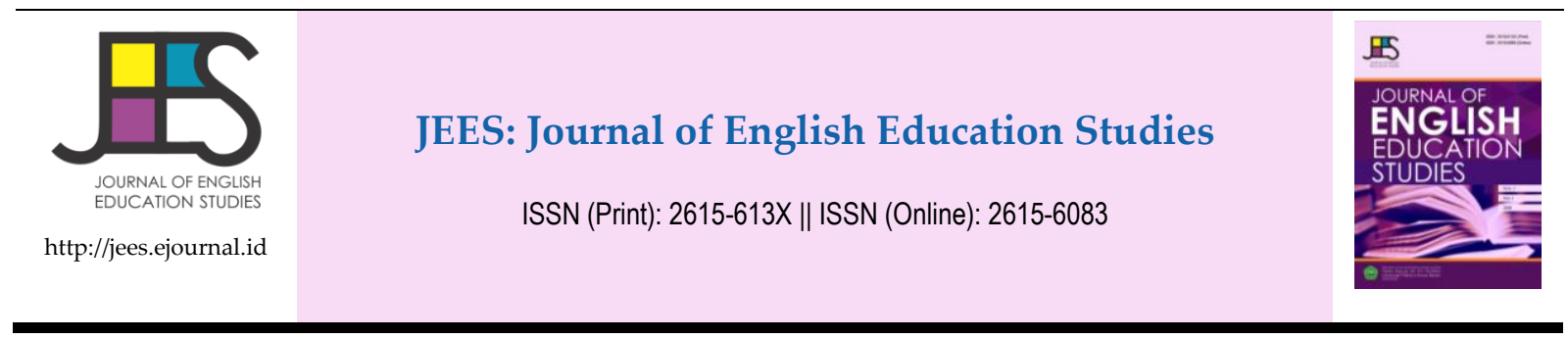

\title{
The Influence of Think, Talk, and Write (TTW) Strategy towards Students' Descriptive Writing Mastery
}

\author{
Riandi ${ }^{1}$, Siti Nurfaujiah
}

${ }^{1}$ English Education Study Program, Teacher Training and Education Faculty of Universitas Mathla'ul Anwar

\begin{abstract}
This research paper was aimed at investigating the influence of Think, Talk, and Write (TTW) stategy towards students' descriptive writing at 2nd grade students of MTS MA Cikaliung. The population of this research was 117. The researcher used simple random sampling to determine the sample. There were two classes taken as sample, VIII C as experimental class with 29 students, and VIII B as control class with 29 students too. This research paper employs the quantitave research design with characteristics of experimental research. The data collection method of this research used a test involving pre-test and post-test. After giving pre-test and post-test, the researcher found that the post-test score of experimental class was higher than the post-test score of control class, which were $2024>1731$. It means that students' writing score was increased after treating by thunk, talk, and write strategy. Through calculating the $\mathrm{t}$-test, the researcher also found that $\mathrm{t}$-count was higher than $\mathrm{t}$-table, which were $4.77>2.005$. It means that there is significant influence of applying think, talk, and write strategy in teaching writing. The findings of this research show that it is significant for the teachers to choose the appropriate stategy for improving students' writing mastery, particularly think, talk, and write strategy as mentioned above. It is also wise for the teachers to identify the students' responses on the strategy used to determine which strategy is appropriate for them. The findings also expect others researcher to investigate the influence of this strategy on other students' English skills.
\end{abstract}

\section{INTRODUCTION}

Language is the best tool or instrument which is used to communicate. It helps human convey a message, express ideas, feelings, thought, and opinion in written or spoken way. Language is used by all people in the world as means of communication. People needs in doing daily activities and making interaction to other people in their life. Anyone cannot interact with the others without language, that's why learning the language become very important.

There are four skills in teaching and learning English that should be mastered by the students. The four skills are: listening, speaking, reading, and writing. Writing is a way of expressing ideas,

\footnotetext{
${ }^{1}$ Corresponding author's address: English Education Study Program of Teacher Training and Education Faculty, Universitas Mathla'ul Anwar, Banten, Indonesia e-mail: rianriandi87@yahoo.com
} 
thought, and feelings into a written form. Writing is an activity of combining words into a piece of paper. Richards in Aripin (2013: 7) stated that "writing needs process, and the process of writing is as a private activity may be broadly seen as comprising four main stages: planning, drafting, revising, and editing."

Langan (2010: 10-11) in his book said that writing is a skill that can be learned with practice. It is not an automatic process; competent writing comes from plain hard work from determination, sweat, and head on battle. The skill of writing can be mastered if someone ready to work, and it is done not in one easy step, but in a series of step. Furthermore, Maggie Sokolik (Nunan, 2015: 78) has pointed out that "writing is a mental process of generating ideas and thinking about how to present them to paper or computer screen by manipulating a pencil, pen, or keys on a keyboard through some steps to produce a final product like an essay, recipe, report, and so on, and the purposes of this process are to express and impress".

Murray and Moore (2006: 21-22) have argued that writing is one of the most difficult of all skills which involves starting, progressing, and finishing a challenging combination of tasks. Writing requires a complicated combination of neurological, physical, cognitive, and affective competencies.

In the other hand, Harmer (2004: 38) said that writing gives the students more time to think than they do in oral activity. They can go through what they know in their minds, and even consult dictionary, grammar books, or other references to help them write. While Boice (Murray and Moore, 2006: 22) stated that "writing is not just influenced by what we know and what we have discovered about a particular phenomenon, it also influenced by what we feel, and more particularly, what we feel about ourselves."

According to the experts' opinion about writing, the writer concludes that writing is a process of generating ideas on a paper or computer screen to express someone's feelings, state, and opinion. Writing becomes the most complicated skills and difficult to do because it requires more competencies and need a complex process, like planning, drafting, revising, and editing. Writing is as a skill that anyone can learn it by practice. More practice and hardworking allow someone to write well. In the other hand, writing activity gives more time to the students to think about what they should write, and when they found a difficulties of vocabulary they can consult it to dictionary.

There are many text types thought in Junior High School, especially in the second grade of Junior High School. One of the texts is descriptive text. A descriptive text has its own language features, there are the uses of adjectives and compound adjective, linking verbs, and the uses of attributive has and have. Lewin $(2003,162)$ in his book said that "Descriptive text describes someone, something, or some places clearly for your audience."

It shows that descriptive describes someone, something, or places. In making a descriptive text, the writer uses words that create an image. The writer helps the readers see, touch, feel, look, or taste the topic of the text. When teaching a descriptive text, the teacher should explain both of organizations and language features to the students, so that the students know that both of them should be included in a descriptive text.

One of strategies in teaching writing is by using TTW (Think, Talk, and Write) strategy. Think, Talk, and Write (TTW) is one of a strategies in teaching and learning process that facilitating the exercise of language both oral and written fluently. This strategy basically built through thinking, speaking, and writing. Applying this strategy will encourage the students to think, talk, and write based on the particular topic.

Huinker and Laughlin (Ali, 2014: 6) states "Think-talk-write strategy build in time for thought and reflection and for the organization of ideas and the testing of those ideas before students are expected to write. The flow of communication progresses from student engaging in thought or reflective dialogue with themselves, to talking and sharing ideas with one another, and to writing". 
The flow advances Think-Talk-Write strategy starting from involvement of students in thinking or dialogue with itself after the reading process. Then talk and share ideas (sharing) with friend before writing. This atmosphere is more effective if done in group between four to six students. In this group of students are requested making notes, explaining, listening and sharing ideas with friends and expressing them through writing

\section{METHOD}

According to Nazir (1983: 35), method is procedural activity of getting a way that aimed to answer general questions or facts. He also explained that there are many methods that can be used for conducting a research, and one of them is experimental research. Sugiyono (2010: 107) stated that "An experimental research is one of a research method which is used to find out the effect of one appropriate treatment to another treatment."

In this research, the writer chose a quasi experiment as a model of research design with nonequivalent control group design. This design, consist of two groups, there were experimental and control group. Both of experimental and control group get a pre-test to measure their basic skill and given a post-test to compare the result of their score before and after they got a treatment.

The post test given after giving a treatment by using Think, Talk, and Write (TTW) strategy to experimental group, and to control group that treated by using a conventional method.

\section{RESULT AND DISCUSSION}

This research was conducted at $2^{\text {nd }}$ grade students of MTs Mathla'ul Anwar Cikaliung SaketiPandeglang. There were four classes took as population, namely VIIA, VIIIB, VIIIC, and VIID, and the researcher took VIII B and VIIIC as a sample. The data were taken from the test score of the two classes which have been chosen as sample of the research. To get the data in this research, the researcher used the achievement test in collecting the data by giving pre-test and post -test for both experimental and control class.

A pre-test was given to know the students' writing basic skills, while a post-test was given to measure students' writing achievement after treated the sample by using Think, Talk, and Write (TTW) strategy towards experimental class and a conventional method towards control class.

After conducting the research, the researcher calculated the data to find out the result of the test, and to know whether there is a significant effect of applying Think, Talk, and Write (TTW) strategy towards students' descriptive writing mastery at the second grade students of MTs Mathla'ul Anwar Cikaliung.

To describe the students' pre-test and post-test score, the researcher makes tablse as follow:

\section{Table 1. The Score of Experimental Class}

\begin{tabular}{cccc} 
No & $\begin{array}{c}\text { Students' } \\
\text { code }\end{array}$ & $\begin{array}{c}\text { Pre-test } \\
\left(X_{1}\right)\end{array}$ & $\begin{array}{c}\text { Post-test } \\
\left(X_{2}\right)\end{array}$ \\
\hline 1. & SE 1 & 65 & 75 \\
2. & SE 2 & 63 & 75 \\
3. & SE 3 & 60 & 72 \\
4. & SE 4 & 60 & 72 \\
5. & SE 5 & 60 & 70 \\
6. & SE 6 & 60 & 70 \\
7. & SE 7 & 60 & 70 \\
8. & SE 8 & 60 & 68 \\
9. & SE 9 & 59 & 68 \\
10. & SE 10 & 55 & 65
\end{tabular}




\begin{tabular}{lccc} 
No & $\begin{array}{c}\text { Students' } \\
\text { code }\end{array}$ & $\begin{array}{c}\text { Pre-test } \\
\left(\mathrm{X}_{1}\right)\end{array}$ & $\begin{array}{c}\text { Post-test } \\
\left(\mathrm{X}_{2}\right)\end{array}$ \\
\hline 11. & SE 11 & 55 & 65 \\
12. & SE 12 & 55 & 65 \\
13. & SE 13 & 55 & 65 \\
14. & SE 14 & 55 & 62 \\
15. & SE 15 & 55 & 60 \\
16. & SE 16 & 50 & 56 \\
17. & SE 17 & 50 & 56 \\
18. & SE 18 & 50 & 55 \\
19. & SE 19 & 45 & 50 \\
20. & SE 20 & 80 & 85 \\
21. & SE 21 & 72 & 85 \\
22. & SE 22 & 70 & 80 \\
23. & SE 23 & 70 & 80 \\
24. & SE 24 & 70 & 80 \\
25. & SE 25 & 65 & 75 \\
26. & SE 26 & 65 & 75 \\
27. & SE 27 & 65 & 75 \\
28. & SE 28 & 65 & 75 \\
29. & SE 29 & 65 & 75 \\
\hline Total & & 1759 & 2024 \\
\hline
\end{tabular}

From table 1, it shows that the total score of pre-test was 1759, and the total score of post-test was 2024.

Table 2. The Score of Control Class

\begin{tabular}{cccc} 
No & $\begin{array}{c}\text { Students' } \\
\text { code }\end{array}$ & $\begin{array}{c}\text { Pre-test } \\
\left(\mathrm{X}_{1}\right)\end{array}$ & $\begin{array}{c}\text { Post-test } \\
\left(\mathrm{X}_{2}\right)\end{array}$ \\
\hline 1. & SC 1 & 60 & 62 \\
2. & SC 2 & 60 & 60 \\
3. & SC 3 & 60 & 60 \\
4. & SC 4 & 60 & 60 \\
5. & SC 5 & 57 & 57 \\
6. & SC 6 & 57 & 57 \\
7. & SC 7 & 45 & 45 \\
8. & SC 8 & 50 & 50 \\
9. & SC 9 & 50 & 50 \\
10. & SC 10 & 50 & 50 \\
11. & SC 11 & 50 & 52 \\
12. & SC 12 & 50 & 52 \\
13. & SC 13 & 52 & 52 \\
14. & SC 14 14 & 52 & 53 \\
15. & SC 15 & 55 & 55 \\
16. & SC 16 & 55 & 55 \\
17. & SC 17 & 55 & 57 \\
18. & SC 18 & 55 & 57 \\
19. & SC 19 & 63 & 63 \\
20. & SC 20 & 63 & 65 \\
21. & SC 21 & 65 & 65 \\
\hline
\end{tabular}




\begin{tabular}{cccc} 
No & $\begin{array}{c}\text { Students' } \\
\text { code }\end{array}$ & $\begin{array}{c}\text { Pre-test } \\
\left(\mathrm{X}_{1}\right)\end{array}$ & $\begin{array}{c}\text { Post-test } \\
\left(\mathrm{X}_{2}\right)\end{array}$ \\
\hline 22. & SC 22 & 65 & 65 \\
23. & SC 23 & 65 & 65 \\
24. & SC 24 & 65 & 65 \\
25. & SC 25 & 80 & 80 \\
26. & SC 26 & 70 & 72 \\
27. & SC 27 & 70 & 70 \\
28. & SC 28 & 70 & 70 \\
29. & SC 29 & 65 & 67 \\
\hline & Total & 1714 & 1731 \\
\hline
\end{tabular}

From table 2, it shows that the pre-test score of control class was 1714, and the post-test score was 1731.

To analyze the data, the writer used statistical composition in calculating the result of the test; calculated the mean of both experimental and control class, and found a significant difference by using t-test.

1) Mean

a. Mean of Experimental Class

Pre-test:

Table 3. Pre-Test Mean of Experimental Class

\begin{tabular}{ccccc}
\hline No & Interval & F & X & F. X \\
\hline 1. & $45-50$ & 4 & 47.5 & 190 \\
\hline 2. & $51-56$ & 6 & 53.5 & 321 \\
\hline 3. & $57-62$ & 7 & 59.5 & 416.5 \\
\hline 4. & $63-68$ & 7 & 65.5 & 458.5 \\
\hline 5. & $69-74$ & 4 & 71.5 & 286 \\
\hline 6. & $75-80$ & 1 & 77.5 & 77.5 \\
\hline & $\sum$ & 29 & & 1749.5 \\
\hline
\end{tabular}

$$
\bar{X}=\frac{1749.5}{29}=60.32
$$

Post-test:

Table 4. Post-Test Mean of Experimental Class

\begin{tabular}{ccccc}
\hline No & Interval & $F$ & $X$ & F.X \\
\hline 1. & $50-55$ & 2 & 52.5 & 105 \\
\hline 2. & $56-61$ & 3 & 58.5 & 175.5 \\
\hline 3. & $62-67$ & 5 & 64.5 & 322.5 \\
\hline 4. & $68-73$ & 7 & 70.5 & 493.5 \\
\hline 5. & $74-79$ & 7 & 76.5 & 535.5 \\
\hline 6. & $80-85$ & 5 & 82.5 & 412.5 \\
\hline & $\sum$ & 29 & & 2044.5 \\
\hline
\end{tabular}

$\bar{X}=\frac{2044.5}{29}=70.5$ 
b. Mean of Control Class

Pre-test:

Table 5. Pre-test Mean of Control Class

\begin{tabular}{|c|c|c|c|c|}
\hline No & Interval & $\mathrm{F}$ & $X$ & F. X \\
\hline 1. & $45-50$ & 6 & 47.5 & 285 \\
\hline 2. & $51-56$ & 6 & 53.5 & 321 \\
\hline 3. & $57-62$ & 6 & 59.5 & 357 \\
\hline 4. & $63-68$ & 7 & 65.5 & 458.5 \\
\hline 5. & $69-74$ & 3 & 71.5 & 214.5 \\
\hline \multirow[t]{2}{*}{6.} & $75-80$ & 1 & 77.5 & 77.5 \\
\hline & $\sum$ & 29 & & 1713.5 \\
\hline
\end{tabular}

$$
\bar{X}=\frac{1713.5}{29}=59.08
$$

Post-test:

Table 6. Post-test Mean of Control Class

\begin{tabular}{ccccc}
\hline No & Interval & $\mathrm{F}$ & $\mathrm{X}$ & $\mathrm{F} . \mathrm{X}$ \\
\hline 1. & $45-50$ & 4 & 47.5 & 190 \\
\hline 2. & $51-56$ & 6 & 53.5 & 321 \\
\hline 3. & $57-62$ & 8 & 59.5 & 476 \\
\hline 4. & $63-68$ & 7 & 65.5 & 458.5 \\
\hline 5. & $69-74$ & 3 & 71.5 & 214.5 \\
\hline 6. & $75-80$ & 1 & 77.5 & 77.5 \\
\hline & $\sum$ & 29 & & 1737.5 \\
\hline
\end{tabular}

$$
\bar{X}=\frac{1737.5}{29}=59.91
$$

2) T-test

$$
\begin{aligned}
t= & \frac{\bar{X} 1-\bar{X} 2}{\sqrt{\frac{S 1^{2}}{n}+\frac{S 2^{2}}{n}}} \\
= & \frac{70.5-59.91}{\sqrt{\frac{79.5664}{29}+\frac{64}{29}}} \\
& =\frac{10.59}{\sqrt{2.74+2.20}} \\
& =\frac{10.59}{\sqrt{4,94}} \\
& =\frac{\mathbf{1 0 . 5 9}}{\mathbf{2 . 2 2}} \\
& =4.77
\end{aligned}
$$

After the $\mathrm{t}$ - count was found, the researcher calculated df (degree of freedom), as follow:

$$
\begin{aligned}
\mathrm{df} & =\left(\mathrm{N} x+\mathrm{N}_{y}-2\right) \\
& =(29+29-2) \\
& =56 \\
\alpha & =2.005
\end{aligned}
$$


Based on the data analyzed by using t-test, it's found that t-count is 4.77 and $\mathrm{df}$ in this case is 56. Based on the table of t-table, the figure of 56 is 2.005. It means that t-count (4. 77) is higher than $t$ table (2.005) in term of statistics, it can be seen as follow: $4.77>2.005$, so $\mathrm{H}_{\mathrm{o}}$ is rejected, and $\mathrm{H}_{\mathrm{a}}$ is accepted. It shows that there is significant influence of applying Think, Talk, and Write Strategy towards students' writing descriptive text.

\section{CONCLUSIONS}

From the finding's analysis and interpretation, the researcher gains some conclusions as follow:

1) Think, Talk, and Write (TTW) strategy in teaching writing has been proven to have an influence on students' writing mastery. This result was encouraged statistically by $\mathrm{t}$-test calculation which shows that null hypothesis (Ho) was rejected. Based on the treatment given, Think, Talk, and Write (TTW) strategy can increase students' interest and motivation.

2) Think, Talk, and Write strategy can develop students' writing mastery. By using this strategy, students' confusing about writing, including vocabulary and grammar, was decreased. It has been proven by comparing pre-test and post-test in each control and experimental class.

3) There is significant effect of teaching writing by using Think, Talk, and Write strategy towards students' writing mastery, and it was proved through computing t-test which showed that $\mathrm{t}$ count was higher than $\mathrm{t}$-table, that can be seen as $4.77>2.005$.

\section{REFERENCES}

Ali, M. N. (2014). Improving the Students' Writing Skill on Descriptive Text by Using Think, Talk, and Write (TTW). [Online]. Available at: http://www.repo.iain-tulungagung.ac.id/95/ [15 March 2017].

Aripin. (2013). The Influence of Teaching Writing Through Pictures as Teaching Media Towards Students' Writing Ability. A Research Paper of English Education Study Program of Teacher Training and Education Faculty, Mathla'ul Anwar University: Unpublished.

Harmer, J. (2004). How to Teach Writing. London: Pearson Longman.

Langan, J. (2010). Exploring Writing: Sentences and Paragraph. New York: McGraw-Hill.

Lewin, L. (2003). Paving the Way in Reading and Writing. USA: Jossey Bass.

Murray, R. \& Moore, S. (2006). The Handbook of Academic Writing. New York: McGraw Hill.

Nazir, M. (1983). Metode Penelitian. Jakarta: Ghalia Indonesia.

Nunan, D. (2015). Teaching English to Speaker of Other Languages: An Introduction. New York: Routledge.

Sugiyono. (2010). Metode Penelitian Pendidikan: Pendekatan Kuantitatif, Kualitatif dan R\&D. Bandung: Alfabeta. 